\title{
Ethnic-Connectedness and Economic Inequality: A Persisting Relationship
}

\author{
Madeline A. Kalbach \\ Kelly H. Hardwick \\ Renata D. Vintila \\ Warren E. Kalbach \\ Department of Sociology \\ University of Calgary \\ Calgary, Alberta, Canada
}

\begin{abstract}
This paper focuses on the relationship between the retention of ethnic or cultural distinctiveness and economic inequality for Ukrainians, Germans, Italians, Chinese, and south East Asians. It uses Canadian census data to test predictions arising from assimilation theory by examining the possible varying effects of religion on economic inequality for the five ethnic groups in order to determine whether assimilation theory and the multidimensional effect of ethnicity can predict within group variations. This analysis lends emphasis to the fact that retention of ethnic-connectedness and distinctiveness may create obstacles for the immigrant attempting to achieve economic success in Canada.
\end{abstract}

Key Words: Ethnic-connectedness, economic inequality, ethnicity, religion, assimilation, integration 
Madeline Kalbach, Kelly H. Hardwick, Renata D. Vintila, Warren E. Kalbach

\section{Résumé}

This paper focuses on the relationship between the retention of ethnic or cultural distinctiveness and economic inequality for Ukrainians, Germans, Italians, Chinese, and south East Asians. It uses Canadian census data to test predictions arising from assimilation theory by examining the possible varying effects of religion on economic inequality for the five ethnic groups in order to determine whether assimilation theory and the multidimensional effect of ethnicity can predict within group variations. This analysis lends emphasis to the fact that retention of ethnic-connectedness and distinctiveness may create obstacles for the immigrant attempting to achieve economic success in Canada.

Mots Clés: Ethnic-connectedness, economic inequality, ethnicity, religion, assimilation, integration

\section{Introduction}

A persistent question in immigration research concerns the significance of an immigrant's ethnic and cultural origins for successful integration into Canadian society. Previous research indicates that the relationship between ethnicconnectedness and income inequality is one that has persisted throughout most of the twentieth century (Kalbach and Kalbach, 1999). This finding has been totally consistent with general assimilation theory and testable hypotheses re assimilation and cultural persistence arising from the work of Gordon (1964), Lieberson (1963) and others (Richmond and Kalbach, 1980; Breton et.al., 1990; Isajiw, Sev'er and Driedger, 1993; Boyd et. al., 1985).

Changes to immigration policy beginning in the 1960s produced a dramatic shift in the character of Canada's immigration stream from being predominantly European to being predominantly non-European. In 1951 nine of the ten top source countries of immigrants to Canada were European with the tenth being the United States. By 1968 one non-European country (Hong Kong) became one of the top ten sources of immigrants to Canada, and from 1991 until the present at least 8 non-European countries could be found in the top ten.

The introduction of the point system in 1967 resulted in major changes in the socioeconomic and cultural characteristics of the arriving immigrants. The purpose of this paper is to extend previous analyses of the significance of the retention of non-British/French cultural identities for the integration of Canada's immigrant population by Kalbach and Kalbach (1999). More specifically, this 
paper focuses on the relationship between the retention of ethnic or cultural distinctiveness and economic inequality for Ukrainians, Germans, Italians, Chinese, and South East Asians. Moreover, it examines the relative contribution of language, educational and occupational status, gender, age, and nativity to variations in total individual income as indicators of the relative integration for those specific ethnic or cultural populations. The importance of this paper is that it goes beyond the work of Vintila (2000) by conducting the analysis separately for each of several major ethnic minority populations rather than for all ethnic groups combined .

\section{Literature Review}

Earlier research based exclusively on census data has demonstrated the utility of employing a multidimensional definition of ethnicity (Richard, 1991; Kalbach and Kalbach, 2000, 1999, 1995; Vintila, 2000). These studies took the multidimensional nature of ethnicity into account by including the religious factor in the definition of ethnicity. Thus Ukrainians, for example, can be categorized according to their level of ethnic-connectedness. Ukrainians who indicated they were Ukrainian Orthodox in the 1991 Census are likely to be more Ukrainian than Ukrainians who reported being Anglican or United Church. Similarly, Chinese identifying with any Eastern Non-Christian religion can be assumed to be more Chinese in their cultural orientation than those Chinese who report being Anglican or United Church. Expanding the definition of ethnicity in this way is a more precise and valid means of approximating the boundaries of the viable ethnic group. In other words, this multidimensional definition makes it possible to identify differential levels of cultural persistence among individuals within each ethnic or cultural group. Kalbach and Kalbach, for example, investigated the relationship between ethnic identity and socioeconomic attainment for selected minority groups in Canada (2000).

Analyses of data from the 1971, 1981 and 1991 censuses indicate that many non-British European groups such as the Ukrainians and Germans who identified with the Anglican or United Church exhibited greater linguistic assimilation and higher socio-economic status than those who were more ethnically connected, e.g., Ukrainian Orthodox and German Lutheran. Furthermore, those who were the least ethnically-connected, e.g., Ukrainians or Germans with No Religious preference exhibited an even higher level of socioeconomic achievement. These results suggest that there are three possible pathways to cultural assimilation and economic integration. Each pathway is related to a level of ethnic-connectedness indicated by the multidimensional definition of ethnicity employed in this analysis. Hence, maintaining a greater degree of ethnic connectedness is the greatest inhibitor of social and economic mobility, while the secular pathway representing the lowest level of ethnicconnectedness, appears to have been the better facilitator of mobility. Analyses of these data for both foreign- and native-born individuals have revealed that the 
significance of ethnic-connectedness appears to be greatest for the foreign born or first generation.

While the results of much of this work has been consistent with the general assimilation model, the changing character of Canada's immigrant population and Canada's immigration policy warrants a continuing examination of this question. There are no assumptions regarding the inevitability of total assimilation of minority groups by the culturally dominant group. The objective of this research has been, and continues to be, to determine the significance of variations in ethnic-connectedness, i.e., cultural persistence, within ethnic origin groups for the integration and socioeconomic achievement of Canada's ethnically diverse population.

\section{Conceptual Framework and Methodology}

For the most part, previous research (Kalbach and Kalbach, 2000;1999; 1995) on the significance of the individual's ethnic origin for integration and assimilation has utilized crosstabular analysis which is mainly descriptive in nature. This paper utilizes multiple regression to carry the analysis one step further in order to examine the relative effects of other independent variables such as language, education, occupation, religion, age and gender on the total income of a selected sample of five specific ethnic origin populations, e.g., Ukrainians, Germans, Italians, Chinese and South Asians in Canada at the time of the 1991 Census. Vintila's research (2000) confirmed the utility of such an approach, in that she found income to vary by gender and by ethnicconnectedness for all ethnic groups combined which is consistent with Kalbach and Kalbach's earlier research (Ibid.). This analysis, however, goes one step beyond her research by conducting the analysis separately for each of these five ethnic populations. In addition, data have never been presented for Italians and South Asians for comparison with the other 3 groups before.

This particular analysis tests predictions arising from assimilation theory by examining the possible varying effects of religion on economic inequality for the five ethnic or cultural groups in order to determine whether assimilation theory and the multidimensional definition of ethnicity can predict within group variations. In other words, do varying levels of ethnic-connectedness have an impact on economic success? Based on ethno-religious groupings and following assimilation theory (Gordon, 1964; Lieberson, 1963; Kalbach 1995, 1999), this paper hypothesizes that within each ethnic group, variation in economic inequality should exist across religious affiliation, i.e., that the level of ethnicconnectedness within ethnic origin groups will vary and this variation should have an effect on economic success. Within each ethnic origin group, the individuals who still identify with their ethnic church, i.e., have a higher level of ethnic-connectedness, will, on average, earn less that those who have become affiliated with a Canadian church such as the Anglican Church of Canada or 
United Church prior to or since establishing residence in Canada (Kalbach, 1995;1999). Furthermore, there should be a negative effect of identifying with any other church or identifying with no church at all when compared to the Canadian church. If assimilation theory is correct, one of the more effective pathways to economic success for immigrants would be to convert to one of Canada's major churches, which would tend to diminish the levels of ethnicconnectedness and its negative effect on economic success.

Ordinary least squares multiple regression (OLS) is utilized to examine the effect of an independent variable or set of independent variables, net the effect of a control variable or a set of control variables, on a continuous or quantitative dependent variable. ${ }^{1}$ Since the hypotheses outlined above include examining the effect of group inclusion on economic success for ethnic origin and across religious groups, while simultaneously controlling for various other factors, it would appear that OLS multiple regression would be the best method to choose. The sample size $(\mathrm{N})$, for all of the groups is weighted using the weight variable derived by Statistics Canada.

More specifically, this paper hypothesizes that within ethnic ancestry, religious affiliation should have strong effects on economic success net other factors. That is, the "effect" of being from a particular ancestry group will vary depending upon the respondent's current religious affiliation. This type of relationship is known as an interaction effect. Modeling and testing interaction effects goes beyond group effect (main effect) models which treat each group as "homogenous" with regard to the dependent variable of interest. Interaction models, on the other hand, predict that capturing main group effects is not, in itself, sufficient. Instead, they allow for a more thorough analysis through their ability to model within-group variation on another pre-specified independent variable (in this case, religion).

Since the primary hypothesis of this paper suggests that the effect of ethnic origin (ancestry) will vary by current religious identity, it would normally be necessary to create interaction terms to test that hypothesis. In OLS multiple regression, interaction terms (or multiplicative terms) are created by multiplying together the independent variables of interest. Multiplicative terms can be created for two (or more) dummy variables or for one dummy variable and a continuous variable. ${ }^{2}$ Interpreting the coefficients for these multiplicative terms, while not as straightforward as interpreting the coefficients for dummy variables, is still not very complicated. The coefficient for a multiplicative term created for two dummy (or categorical) variables is still interpreted as the difference in means on the dependent variable. But now, the groups being compared are more specific.

However, an alternative method to that of creating interaction terms can be used to test the hypotheses outlined in this paper. The alternative method involves "physically" controlling for ethnicity and then examining the effects of the 
independent variables of interest. ${ }^{1}$ In some instances, the "physical" method of examining interaction effects has several distinct advantages, besides being easier to interpret, over the method that creates a set of interaction terms. In the latter method, the number of "variables" (i.e., multiplicative terms) needed can, under certain conditions that are not very uncommon, become somewhat unmanageable. Also, interpreting higher order interactions (i.e., three way interactions) can be difficult if not impossible. For ease of interpretation, then, the method of physically controlling for ethnic ancestry will be used. This means that the model will be analyzed for each ethnic origin or cultural group separately.

\section{Data Source and Variable Definitions}

The data source used for this analysis is the 1991 Census of Canada Public Use Microdata File (Individual File) and the method of analysis is OSL regression. The analysis focuses on those individuals belonging to the five groups who are 15 years of age and over and in the labour force. The variables used to operationally define the social, cultural and economic concepts employed in this analysis are limited to the standard census variables as defined in the 1991 Census Dictionary (Statistics Canada, 1992).. The variable definitions are as follows:

1. Total Income refers to the total money income for individuals 15 years of age and older during the calendar year 1990. Total income includes income from wages and salaries before deductions including military pay and allowances, tips, commissions and cash bonuses, net non-farm self-employment income, net farm self-employment income, family allowances, federal child tax credits, old age security pension, Canada or Quebec pension plan income, unemployment benefits, dividends and interest paid on bonds, deposits, and savings, and other money income. Total income is utilized as an indicator of economic status rather then income received based only on wages and salaries because it includes all sources of income and therefore is a more compete indicator of SES. It is common practice to transform income variables due to their skewed nature (i.e., logarithmic transformation). However, when comparing across groups, it has been effectively argued (Wanner, 1998) that transforming income in this manner results in coefficients with characteristics like standardized coefficients. As a result, we chose not to use the log of income in this analysis.

2. Ethnic Origin refers to a respondent's ethnic ancestry before coming to this continent. Respondents could indicate more than one ancestry. Ethnic origin was recoded into a new variable to separate those individuals who indicated single origin from those who indicated multiple origins. The multiple origin category is used as the comparison 
group. Respondents who indicate a single origin are assumed to be less assimilated than those who indicate a multiple origin.

3. Nativity refers to the place of birth of the respondent. Place of birth is dichotomized into native born and foreign born. The native-born category is used as the reference group.

4. Age refers to the respondent's age (in years) at their last birthday and is derived from the respondent's date of birth. Age squared is used to capture the curvilinear relationship between age and total income.

5. Sex refers to the gender of the respondent. Gender is a qualitative variable in which a dummy variable was created for females. Hence, Male is used as the reference or base comparison group.

6. Home Language refers to the language spoken most often at home. If a respondent indicated an ethnic language as the language spoken most often at home it was coded 1 . Therefore, those who indicated that their language spoken at home was English or French (or both) served as the comparison group in all of the analyses.

7. Mother Tongue refers to the first language learned as a child and still understood at the time of the Census. If a respondent indicated an ethnic mother tongue it was coded 0 and is utilized as the comparison group. English or French or both mother tongues were coded as 1.

8. Education refers to the total years of schooling and is utilized as an indicator of socioeconomic status. This variable was recoded and treated as a continuous variable.

9. Occupation is dichotomized into a "managerial and professional" and "non-managerial and professional". Thus, respondents indicating at least a "professional" occupation (including middle and senior managers) were coded 1 . Otherwise, respondents were coded 0 . A dummy variable was created for those with a professional and/or management occupation making those employed in occupations other than "professional" the reference or comparison group. Occupation is utilized as a measure of socioeconomic status.

10. Religion refers to specific groups or bodies, denominations, sects or cults or other religiously defined communities or systems of belief. Dummy variables were created for the Anglican and United Church since they represent the "Canadian" churches, the ethnic church, Roman Catholic, all Other religious affiliations and No Religion. Respondents indicating an affiliation with the Anglican or United Churches, i.e., the 
Madeline Kalbach, Kelly H. Hardwick, Renata D. Vintila, Warren E. Kalbach

Canadian Churches, form the reference group. For the separate ethnic group analyses, the recoding of religious affiliation varies relative to a group's "ethnic church." For example, for Ukrainians the ethnic church was identified as Ukrainian Orthodox and Ukrainian Catholic. Thus, a dummy variable was created for this group to be compared with the Anglican/United group (the reference group) as well as the Other Catholic, Other, and No Religion. This allows for a more definitive investigation of the hypotheses regarding ethnic-connectedness.

\section{Analysis}

Given the hypotheses generated from assimilation theory and the concept of ethnic-connectedness outlined above, the emergence of a distinct pattern of results across all of the ethnic groups analyzed is expected. First, being foreignborn is expected to have a significant negative effect on income for each of the five groups because being foreign born is associated with a higher level of ethnic-connectedness compared to that of their native-born counterparts. Secondly, it is predicted that the effect of mother tongue will disappear when home language is controlled since it is likely that individuals born in Canada, while they may have learned an ethnic mother tongue, most likely it's use as the dominant language in the home will diminish over time. This may be due to the fact that they learn English/French at school, and are therefore, more likely to use English or French more often at home than their foreign-born counterparts. If an ethnic language is spoken most often at home which indicates a higher level of ethnic-connectedness than when only English and/or French are spoken. It is predicted that there will be a stronger negative effect of home language on income compared to the effect on income for those who are less ethnicallyconnected through language. Similar results are expected for the mother tongue variable.

Thirdly, it is expected that individuals of the five ethnic or cultural groups who reported only one ethnic or cultural ancestry at the time of the 1991 Census will, on average, earn less than respondents of the five groups who reported multiple ethnic or cultural ancestries. It is argued that those who indicate only one ethnic ancestry are more ethnically-connected than those who reported more than one. The latter tend to be less ethnically-connected than the former by virtue of the fact that there has been ethnic-intermarriage in their background making it likely that ties to one or the other ethnic or cultural origins may have been weakened.

Finally, it is expected that a current religious affiliation reflecting a conversion to one of Canada's major Protestant churches, i.e., Anglican and United Church, would diminish a group's level of ethnic-connectedness thus weakening its negative impact on economic success. Consequently, the strength of the effect should vary across ethnic groups having a stronger negative effect on income for respondents reporting an ethnic church affiliation compared to those who claim 
No Religion or Anglican or United Church affiliation, at least for Canada's newer immigrant populations. The negative effects of being ethnicallyconnnected on income for the older European immigrant groups (German and Ukrainian) are expected to be stronger for those who claim affiliation with their ethnic church than those who are Anglican or United Church.

As discussed previously, given the hypotheses of this paper, OLS multiple regression with dummy variables is the most appropriate method of analysis. Two models were analyzed using OLS regression for each of the five ethnic groups, (Ukrainians, Germans, Italians, Chinese and South Asians). Model 1 for each group includes nativity and the "language" variables plus all of the control variables. Model 2 for each ethnic group includes all of the variables in Model 1 with the addition of the religion dummy variables. That is, Models 1 and 2 are nested models such that Model 2 builds on Model 1 by introducing religion. The two models were run in this manner in order to obtain a more detailed understanding of how various levels of ethnic-connectedness not only affects economic success but also to improve our definition of ethnicity by making it more multidimensional.

\section{Model 1}

Tables 1 through 5 presents the result for the multiple regression analysis. The results of Model 1 reveal the effects of nativity, age, age squared, gender, home language, mother tongue, education, occupation and being a single origin on total income of Germans, Ukrainians, Italians, South Asians and Chinese. In general, Model 1 reveals that the coefficients are as expected and are remarkably constant across the five ethnic groups for age, age squared, gender, education and occupation. Their sign is the same and they vary little in magnitude.

Having an ethnic language spoken most often at home, reflecting a high degree of ethnic-connectedness, has the greatest affect on income for the Chinese followed by the Germans and has the least effect on the income of South Asians. The latter finding may reflect the fact that the proportion of South Asians speaking their ethnic language at home may be small because many tend to be fluent in English on arrival in Canada. As predicted, the effect of having an ethnic mother tongue seems to be accounted for by home language for three of the ethnic groups. Italians and Ukrainians are the exceptions. Perhaps the former is due to the fact that Italians are a relatively new European immigrant group and as such still has relatively large proportions of second generation native born who still claim an Italian mother tongue. However, it is likely that the language used in the home is English/French making these individuals less ethnically-connected than their counterparts who speak Italian most often at home as well as having an Italian mother tongue. This may account for the positive effect of the Italian language on income. As for Ukrainians, having both an ethnic mother tongue and still mostly speaking an ethnic language at 
Table 1

Regression of Total Income on Selected Independent Variables for the German Population, 15 Years of Age and Over and in the Labour Force, Canada 1991

\begin{tabular}{|c|c|c|}
\hline Variables & Model 1 & Model 2 \\
\hline Nativity & $\begin{array}{l}-200.53 * \\
(-3.93)\end{array}$ & $\begin{array}{r}-113.27 \\
(-2.22)\end{array}$ \\
\hline Age & $\begin{array}{r}2082.44 * * \\
(356.82)\end{array}$ & $\begin{array}{l}2082.57 * * \\
(356.32)\end{array}$ \\
\hline $\operatorname{Age}^{2}$ & $\begin{array}{l}-19.61^{* *} \\
(-270.82)\end{array}$ & $\begin{array}{l}-19.62 * * \\
(-270.93)\end{array}$ \\
\hline Gender & $\begin{array}{c}-12038.36^{* *} \\
(-406.98)\end{array}$ & $\begin{array}{c}-12074.17 * * \\
(-407.77)\end{array}$ \\
\hline Home Language & $\begin{array}{c}-4380.29 * * \\
(-48.64)\end{array}$ & $\begin{array}{c}-4343.43 * * \\
(-48.07)\end{array}$ \\
\hline Mother Tongue & $\begin{array}{l}111.21 \\
(2.09)\end{array}$ & $\begin{array}{c}314.76 \\
(5.80)\end{array}$ \\
\hline Education & $\begin{array}{c}1098.62 * * \\
(204.74)\end{array}$ & $\begin{array}{c}1093.73 * * \\
(203.86)\end{array}$ \\
\hline Occupation & $\begin{array}{c}10584.94 * * \\
(265.70)\end{array}$ & $\begin{array}{c}10580.80 * * \\
(265.80)\end{array}$ \\
\hline $\begin{array}{l}\text { Single Ethnic } \\
\text { Origin }\end{array}$ & $\begin{array}{l}-76.20 \\
(-2.22)\end{array}$ & $\begin{array}{l}-66.88 \\
(-1.91)\end{array}$ \\
\hline Catholic Church & & $\begin{array}{c}-678.38 * * \\
(-15.49)\end{array}$ \\
\hline Ethnic Church & & $\begin{array}{c}-1433.42 * * \\
(-28.35)\end{array}$ \\
\hline Other Church & & $\begin{array}{c}-2193.65^{* *} \\
(-46.99)\end{array}$ \\
\hline No Religion & & $\begin{array}{c}-1364.12 * * \\
(-27.94)\end{array}$ \\
\hline Constant & -31820.31 & -30628.67 \\
\hline $\mathbf{R}^{2}$ & .333 & .334 \\
\hline N (Weighted) & 1571265 & 1571265 \\
\hline
\end{tabular}

Source: Statistics Canada. 1991 Census of Canada. PUMF, Individual File.

Notes: All coefficients reported are unstandardized. t-values in parentheses.

* denotes a t-value greater than 2.5 and less than 4 (moderate strength for this sample size).

** denotes a t-value greater than 4 (strong to very strong for this sample size).

The ethnic church includes Lutheran, German Catholic, Mennonite and Hutterite. 
Table 2

Regression of Total Income on Selected Independent Variables for the

Ukrainian Population, 15 Years of Age and Over and in the Labour Force, Canada 1991

\begin{tabular}{|c|c|c|}
\hline Variables & Model 1 & Model 2 \\
\hline Nativity & $\begin{array}{c}1404.00 * * \\
(11.70)\end{array}$ & $\begin{array}{c}1446.83^{* * *} \\
(12.05)\end{array}$ \\
\hline Age & $\begin{array}{l}2164.23 * * \\
(228.77)\end{array}$ & $\begin{array}{l}2163.93 * * \\
(228.68)\end{array}$ \\
\hline $\mathrm{Age}^{2}$ & $\begin{array}{l}-20.22 * * \\
(-173.05)\end{array}$ & $\begin{array}{l}-20.23 * * \\
(-173.14)\end{array}$ \\
\hline Gender & $\begin{array}{c}-11237.85^{* *} \\
(-233.33)\end{array}$ & $\begin{array}{c}-11276.75^{* *} \\
(-233.39)\end{array}$ \\
\hline Home Language & $\begin{array}{c}-3825.92 * * \\
(-24.86)\end{array}$ & $\begin{array}{c}-3780.29 * * \\
(-24.40)\end{array}$ \\
\hline Mother Tongue & $\begin{array}{c}-1289.00^{* * *} \\
(-16.61)\end{array}$ & $\begin{array}{c}-1224.20^{* * *} \\
(-15.31)\end{array}$ \\
\hline Education & $\begin{array}{c}1368.71 * * \\
(147.88)\end{array}$ & $\begin{array}{c}1367.72 * * \\
(147.77)\end{array}$ \\
\hline Occupation & $\begin{array}{c}9861.34 * * \\
(151.13)\end{array}$ & $\begin{array}{c}9857.99 * * \\
(151.09)\end{array}$ \\
\hline Single Ethnic Origin & $\begin{array}{l}-24.26 \\
(-0.45)\end{array}$ & $\begin{array}{l}-29.03 \\
(-0.51)\end{array}$ \\
\hline Catholic Church & & $\begin{array}{c}-302.40 * * \\
(-4.22)\end{array}$ \\
\hline Ethnic Church & & $\begin{array}{c}-616.32 * * \\
(-7.41)\end{array}$ \\
\hline Other Church & & $\begin{array}{c}-682.57 * * \\
(-8.47)\end{array}$ \\
\hline No Religion & & $\begin{array}{c}-795.13 * * \\
(-10.03)\end{array}$ \\
\hline Constant & -36771.43 & -36292.20 \\
\hline $\mathbf{R}^{2}$ & .330 & .330 \\
\hline N (Weighted) & 578566 & 578566 \\
\hline
\end{tabular}

Source: Statistics Canada. 1991 Census of Canada. PUMF, Individual File.

Notes: All coefficients reported are unstandardized. t-values in parentheses.

* denotes a t-value greater than 2.5 and less than 4 (moderate strength for this sample size).

**denotes a t-value greater than 4 (strong to very strong for this sample size).

The ethnic church includes Ukrainian Catholic and Ukrainian Orthodox. 
Table 3

Regression of Total Income on Selected Independent Variables for the Italian Population, 15 Years of Age and Over and in the Labour Force, Canada 1991

\begin{tabular}{|c|c|c|}
\hline Variables & Model 1 & Model 2 \\
\hline Nativity & $\begin{array}{c}-1548.62 * * \\
(-22.80)\end{array}$ & $\begin{array}{c}-1541.49 * * \\
(-22.67)\end{array}$ \\
\hline Age & $\begin{array}{l}2482.82 * * \\
(238.69)\end{array}$ & $\begin{array}{l}2489.77 * * \\
(239.02)\end{array}$ \\
\hline $\mathrm{Age}^{2}$ & $\begin{array}{l}-23.66^{* * *} \\
(-184.57)\end{array}$ & $\begin{array}{l}-23.74 * * \\
(-185.02)\end{array}$ \\
\hline Gender & $\begin{array}{c}-10588.63 * * \\
(-226.34)\end{array}$ & $\begin{array}{c}-10601.38^{* *} \\
(-226.56)\end{array}$ \\
\hline Home Language & $\begin{array}{c}-3402.85^{* *} \\
(-51.89)\end{array}$ & $\begin{array}{c}-3439.30 * * \\
(-52.43)\end{array}$ \\
\hline Mother Tongue & $\begin{array}{c}1201.60 * * \\
(18.10)\end{array}$ & $\begin{array}{l}1104.90^{* *} \\
(16.56)\end{array}$ \\
\hline Education & $\begin{array}{c}873.32 * * \\
(115.67)\end{array}$ & $\begin{array}{c}872.41 * * \\
(115.55)\end{array}$ \\
\hline Occupation & $\begin{array}{c}10787.18 * * \\
(170.80)\end{array}$ & $\begin{array}{c}10766.66 * * \\
(170.48)\end{array}$ \\
\hline Single Ethnic Origin & $\begin{array}{c}1117.15^{* *} \\
(17.52)\end{array}$ & $\begin{array}{c}843.49 * * \\
(12.61)\end{array}$ \\
\hline Ethnic Church & & $\begin{array}{l}161.53 \\
(1.30)\end{array}$ \\
\hline Other Church & & $\begin{array}{c}-1680.06^{* *} \\
(-11.03)\end{array}$ \\
\hline No Religion & & $\begin{array}{c}-918.12 * * \\
(-6.15)\end{array}$ \\
\hline Constant & -36596.85 & -36443.27 \\
\hline $\mathbf{R}^{2}$ & .316 & .316 \\
\hline N (Weighted) & 645133 & 645133 \\
\hline
\end{tabular}

Source: Statistics Canada. 1991 Census of Canada. PUMF, Individual File.

Notes: All coefficients reported are unstandardized. t-values in parentheses. * denotes a t-value greater than 2.5 and less than 4 (moderate strength for this sample size).

** denotes a t-value greater than 4 (strong to very strong for this sample size). The ethnic church is the Roman Catholic church. 
Table 4

Regression of Total Income on Selected Independent Variables for the South Asian Population, 15 Years of Age and Over and in the Labour Force, Canada 1991

\begin{tabular}{|c|c|c|}
\hline Variables & Model 1 & Model 2 \\
\hline Nativity & $\begin{array}{c}899.86^{* *} \\
(6.15)\end{array}$ & $\begin{array}{l}1132.42 * * \\
(7.67)\end{array}$ \\
\hline Age & $\begin{array}{l}2160.61^{* *} \\
(113.56)\end{array}$ & $\begin{array}{l}2162.28^{* *} \\
(113.71)\end{array}$ \\
\hline $\mathrm{Age}^{2}$ & $\begin{array}{l}-21.15^{* *} \\
(-88.73)\end{array}$ & $\begin{array}{c}-21.29 * * \\
(-89.28)\end{array}$ \\
\hline Gender & $\begin{array}{c}-8318.49 * * \\
(-99.46)\end{array}$ & $\begin{array}{c}-8338.70^{* * *} \\
(-99.72)\end{array}$ \\
\hline Home Language & $\begin{array}{c}-2357.75^{* *} \\
(-17.25)\end{array}$ & $\begin{array}{c}-2171.97 * * \\
(-15.80)\end{array}$ \\
\hline Mother Tongue & $\begin{array}{c}247.14 \\
(1.87)\end{array}$ & $\begin{array}{c}771.29 * * \\
(5.62)\end{array}$ \\
\hline Education & $\begin{array}{c}869.91 * * \\
(74.88)\end{array}$ & $\begin{array}{c}854.92 * * \\
(73.33)\end{array}$ \\
\hline Occupation & $\begin{array}{c}10275.69^{* *} \\
(86.48)\end{array}$ & $\begin{array}{c}10281.49^{* *} \\
(86.52)\end{array}$ \\
\hline Single Ethnic Origin & $\begin{array}{c}-407.41 * \\
(-3.27)\end{array}$ & $\begin{array}{l}53.25 \\
(0.416)\end{array}$ \\
\hline Catholic Church & & $\begin{aligned}- & 3449.18^{* *} \\
& (-12.86)\end{aligned}$ \\
\hline Ethnic Church & & $\begin{array}{c}-4588.64 * * \\
(-17.70)\end{array}$ \\
\hline Other Church & & $\begin{array}{c}-3017.12 * * \\
(-10.62)\end{array}$ \\
\hline No Religion & & $\begin{array}{c}-3771.65^{* *} \\
(-12.11)\end{array}$ \\
\hline Constant & -33167.70 & -29639.07 \\
\hline $\mathbf{R}^{2}$ & .321 & .322 \\
\hline N (Weighted) & 174866 & 174866 \\
\hline
\end{tabular}

Source: Statistics Canada. 1991 Census of Canada. PUMF, Individual File.

Notes: All coefficients reported are unstandardized. t-values in parentheses.

* denotes a t-value greater than 2.5 and less than 4 (moderate strength for this sample size).

** denotes a t-value greater than 4 (strong to very strong for this sample size). The ethnic church consists of Eastern Non-Christian religions. 
Table 5

Regression of Total Income on Selected Independent Variables for the

Chinese Population, 15 Years of Age and Over and in the Labour Force, Canada 1991

\begin{tabular}{|c|c|c|}
\hline Variables & Model 1 & Model 2 \\
\hline Nativity & $\begin{array}{c}-875.76^{* *} \\
(-8.21)\end{array}$ & $\begin{array}{c}-889.04 * * \\
(-8.25)\end{array}$ \\
\hline Age & $\begin{array}{l}2376.53 * * \\
(165.01)\end{array}$ & $\begin{array}{l}2367.79 * * \\
(164.67)\end{array}$ \\
\hline $\mathrm{Age}^{2}$ & $\begin{array}{l}-23.56^{* *} \\
(-132.70)\end{array}$ & $\begin{array}{l}-23.59 * * \\
(-134.10)\end{array}$ \\
\hline Gender & $\begin{array}{c}-6473.91 * * \\
(-100.66)\end{array}$ & $\begin{array}{c}-6610.23 * * \\
(-102.65)\end{array}$ \\
\hline Home Language & $\begin{array}{c}-5994.07^{* *} \\
(-68.88)\end{array}$ & $\begin{array}{c}-5653.28^{* *} \\
(-64.55)\end{array}$ \\
\hline Mother Tongue & $\begin{array}{l}23.33 \\
(0.21)\end{array}$ & $\begin{array}{c}585.32 * * \\
(5.08)\end{array}$ \\
\hline Education & $\begin{array}{c}742.65 * * \\
(83.85)\end{array}$ & $\begin{array}{c}705.50^{* * *} \\
(78.19)\end{array}$ \\
\hline Occupation & $\begin{array}{c}9206.62 * * \\
(117.31)\end{array}$ & $\begin{array}{c}9142.35 * * \\
(116.65)\end{array}$ \\
\hline Single Ethnic Origin & $\begin{array}{c}1404.09^{* *} \\
(10.68)\end{array}$ & $\begin{array}{c}1864.18^{* *} \\
(14.10)\end{array}$ \\
\hline Catholic Church & & $\begin{array}{c}-2388.62 * * \\
(-14.07)\end{array}$ \\
\hline Ethnic Church & & $\begin{array}{c}-5021.12^{* *} \\
(-27.39)\end{array}$ \\
\hline Other Church & & $\begin{array}{c}-4329.88^{* *} \\
(-25.07)\end{array}$ \\
\hline No Religion & & $\begin{array}{c}-4596.58^{* *} \\
(-28.98)\end{array}$ \\
\hline Constant & -34690.21 & -30795.43 \\
\hline $\mathbf{R}^{2}$ & .267 & .270 \\
\hline N (Weighted) & 347266 & 347266 \\
\hline
\end{tabular}

Source: Statistics Canada. 1991 Census of Canada. PUMF, Individual File.

Notes: All coefficients reported are unstandardized. t-values in parentheses.

* denotes a t-value greater than 2.5 and less than 4 (moderate strength for this sample size).

** denotes a t-value greater than 4 (strong to very strong for this sample size).

The ethnic church consists of Eastern Non-Christian religions. 
home indicates a higher level of ethnic-connectedness than their counterparts who are less ethnically-connected through language. This lends supports to the major hypothesis of this paper.

The expected negative effects of being of a single ethnic ancestry on income is only true for the South Asians. Clearly, more research is necessary to determine the effects of being of a single ethnic ancestry on economic integration and the reasons why this may not be true.

\section{Model 2}

The analysis presented below focuses on Model 2 as shown in Tables 1 through 5 for each of the ethnic groups. In general, Model 2 fails to significantly alter the sign and magnitude of the co-efficients for age, age squared, gender, education and occupation. The addition of religion to the definition of ethnicconnectedness does not change the sign or the magnitude of the coefficients for home language for any of the groups. Individuals belonging to each of the five groups who speak their ethnic language most often at home compared to those who speak English and/or French still earn significantly less income. Thus, the most ethnically-connected individuals through language spoken most often at home earn less than their English or French speaking counterparts. This continues to lend support to the major hypothesis of this paper.

The addition of religion to the definition of ethnicity as shown in Model 2 reveals that mother tongue now has a significant effect on income for Germans, South Asians and the Chinese, and also continues to be significant for Italians. Thus, Italians, Germans, South Asians and the Chinese earn significantly less money than their less ethnically-connected counterparts who claim English and /or French as their mother tongue. This is consistent with the hypothesis regarding the effect of higher levels of ethnic-connectedness and lower levels of economic attainment.

Model 2 reveals the effect of levels of ethnic-connectedness on total income for individuals who reported their cultural origins as Chinese, South Asian, Italian, Ukrainian and German at the time of the 1991 Census. The findings for Germans, South Asians and the Chinese indicate that there is a significant negative impact for current affiliation with the ethnic church on total income compared to affiliation with the Anglican or United Church of Canada. There is also a significant negative impact on total income for those indicating no church preference compared to affiliation with the Anglican or United Church. The latter or more secular level of ethnic-connectedness has a lesser impact on total income than the more ethnically-connected affiliation. These findings support the major hypothesis of this analysis. There is no significant effect of affiliation with the ethnic church for Italians, but there is a significant negative effect on income for those Italians who indicated No Religion. The effect of religion for 
Madeline Kalbach, Kelly H. Hardwick, Renata D. Vintila, Warren E. Kalbach

Ukrainians differs from the rest in that those who identify with no particular church earn less money than those who claim an affiliation with their ethnic church.

The addition of religion to the model fails to alter the sign of single origin coefficients or significantly change the magnitude of the coefficents for the Italians and Chinese, but the variable now has no significant effect for South Asians.

It appears that the addition of religion to the model is beneficial, especially in relation to supporting the idea of the need for a multidimensional definition of ethnicity and therefore more reflective of greater or lesser levels of ethnicconnectedness.

\section{Summary and Conclusions}

The pattern of effects for those of Chinese origin showed the greatest support for assimilation theory and the concept of ethnic-connectedness when compared to the other groups presented in this paper. Only a few results seemed to go against the predictions of assimilation theory, but the overall patterns for all of the groups lend support to the concept of ethnic-connectedness that is derived from assimilation theory. For all the groups, religion makes a difference. For four out of the five groups, the effect of not affiliating with either the Anglican or United Church was strong and negative. For two of the groups, the South Asians and the Chinese, the pattern of religious effects is predicted exactly from assimilation theory and the notion of ethnic-connectedness. For two of the groups, the Italian and the Chinese, the effect of being foreign born was negative and strong. Clearly, the results from this analysis showed support for the concept of ethnic-connectedness as derived from assimilation theory.

Model 2 in each of the five analyses explains the largest amount of variance for the Ukrainians at 34 per cent, while the least variance in income is explained for the Chinese. However, in every case the model increased the explained variation in income levels by about 11 percentage points from Vintila's (2000) analysis when ethnicity was utilized as an independent variable. This confirms earlier findings based on simpler cross-tabular analysis that greater levels of ethnic-connectedness as reflected by a multidimensional definition of ethnicity generally results in lower levels of income. Hence, lower levels of ethnicconnectedness, as reflected in affiliation with the Canadian church, is apparently one of the better pathways to economic integration for most ethnic or cultural groups. It appears that this would hold true for most immigrant groups in Canadian society given that Kalbach and Kalbach's previous but mainly descriptive research also found this to be true for a large number of ethnic populations (Ibid). While the increments in R-Squareds for Model 2 generally appear to be small or the same as in Model 1, it can be argued that the R- 
Squareds are statistically significant by virtue of the sample size, which in itself, often results in small changes in the R-squared. It can also be argued that the religion coefficients appear to be substantively significant, sometimes in the thousands of dollars per year. In the end, Model 2 shows that religion has a strong effect on income. This is interpreted to mean that ethnic-connectedness affects income, and thus, religion has improved our definition and understanding of ethnicity.

Although the confirmatory patterns are interesting, the ambiguities or "mixed" results remain to be explained. The results seem to indicate, first, that a strong interaction effect might exist between language and religion. In fact, the concept of ethnic-connectedness would predict just such an interaction suggesting that those affiliated with the "ethnic" church who continue to use a language other than either English or French in the home should experience less economic success than any other group. Second, the results also appear to suggest that the process of assimilation and economic success may be quite different across ethnic groups or that some ethnic groups may "cluster" into specific and "unique" patterns of assimilation and economic success. If this is the case, then the next step might be to further refine the multi-dimensional definition of ethnic identity by including language.

Gender had a constant and strong, negative effect across all five of the ethnic groups presented in this analysis. Therefore, Ukrainian, German, Italian, Chinese and South Asian women earned significantly less than their male counterparts no matter which church they affiliated with. However, as was true for males, the Canadian church was also the better pathway of assimilation for women.

The findings of this paper also suggest that the increasing emphasis on an immigrant's ability to speak either English or French (through the selection process) will help to ensure greater income equality in the future. It appears that Germans have already reached convergence in economic integration between their native and foreign-born counterparts in terms of levels of income which suggests that some of Canada's other ethnic groups may not be far behind, particularly the older European immigrant groups.

This analysis makes it very clear that the better pathway to assimilation and socioeconomic status equity for the Germans, Ukrainians, Italians, Chinese and South Asians is affiliation with the Canadian church and to a lesser extent for those claiming affiliation with no church who earned lower levels of income than those claiming affiliation with a Canadian church, but still had higher than those claiming affiliation with their ethnic church. This analysis suggests that of three possible pathways to successful economic integration, maintaining a greater degree of ethnic-connectedness through identification with an ethnic church is the least successful pathway, while the Canadian church pathway is the best facilitator of mobility. It was previously thought that the secular 
pathway was better for some ethnic or cultural groups. It seems, then, that the use of multiple regression analysis is a better tool for understanding social and economic mobility as it relates to ethnic-connectedness as defined in this analysis.

In summary, the refinement in methodology utilized in this analysis reveals that assimilation into the host society facilitates higher levels of socioeconomic integration, particularly with respect to cultural characteristics such as religious affiliation and language. Moreover, this argues against encouraging immigrants to maintain some of their culturally distinctive characteristics as espoused in Canada's multiculturalism policy. It would appear that both immigrants and subsequent generations may indeed be handicapped by retention of high levels of ethnic-connectedness and distinctiveness. While it is recognized that one's ethnicity has been shown to be both a resource and a drawback for some groups (Isajiw, Sev'er and Driedger, 1993), this analysis emphasizes the obstacles that retention of ethnic-connectedness and distinctiveness may create for the immigrant attempting to achieve economic success in Canada.

\section{Acknowledgements:}

This research was funded, in part by Heritage Canada and the Prairie Centre of Excellence for Research on Immigrants and Integration. This paper is a revision of an earlier version presented at the Statistics Canada, Economic Conference 2000, May 15-16, 2000, Ottawa, Ontario.

\section{End Notes:}

1. While OLS multiple regression techniques are appropriate when modeling with categorical independent variables, they are not appropriate when modeling with a categorical dependent variable. When faced with a categorical dependent variable, an alternative analytical technique should be used. The most common alternative makes a logit transformation to the categorical dependent variable and uses maximum likelihood estimation to obtain the model parameters.

2. Multiplicative or interaction terms can also be created for two continuous variables. In other words, hypotheses regarding interaction effects need not be restricted to categorical variables and hypotheses regarding group or category differences 
Ethnic-Connectedness and Economic Inequality:

A Persisting Relationship

\section{References:}

Boyd Monica, John Goyder, Frank E. Jones, Hugh A. McRoberts, Peter C. Pineo, John Porter. 1985. "Introduction: The Canadian Mobility Study; Approaches and Procedures," in Ascription and Achievement: Studies in Mobility and Status Attainment in Canada. Monica Boyd, John Goyder, Frank E. Jones, Hugh A. McRoberts, Peter C. Pineo, and John Porter (eds.). Don Mills, Ontario, Canada: Oxford University Press Canada.

Breton, Raymond, Wsevolod W. Isajiw, Warren E. Kalbach, Jeffrey G. Reitz. 1990. Ethnic Identity and Equality: Varieties of Experience in a Canadian City. Toronto: University of Toronto Press.

Gordon, Milton M. 1964. Assimilation in American Life: The Role of Race, Religion, and National Origins. New York: Oxford University Press.

Isajiw, Wsevolod W., Aysan Sev'er, and Leo Driedger. 1993."Ethnic Identity and Social Mobility: A test of the 'drawback model'." Canadian Journal of Sociology, 18 (2):177-196.

Kalbach , Madeline A. and Warren E. Kalbach. 2000. "The Importance of Ethnic-Connectedness for Canada's Postwar Immigrants," in Perspectives on Ethnicity in Canada: A Reader, Madeline A. Kalbach and Warren E. Kalbach (eds.). Toronto: Harcourt Canada

Kalbach, Madeline A. and Warren E. Kalbach. 1999. "Persistence of Ethnicity and Inequality Among Canadian Immigrants," Canadian Studies in Population, 26(1): 83-105.

Kalbach, Madeline A. and Warren E. Kalbach. 1995. "Ethnic Diversity and Persistence as Factors in Socioeconomic Inequality: A Challenge for the Twenty-First Century," paper presented at the Federation of Canadian Demographers Symposium, Toward XXIst Century: Emerging SocioDemographic Trends and Policy Issues in Canada. St. Paul University, Ottawa, Ontario, October 23-25, 1995.

Kalbach, Warren E. \& Madeline A. Richard. 1980. "Differential Effects of Ethno-Religious Structure on Linguistic Trends and Economic Achievements of Ukrainian Canadians," in Changing Realities: Social Trends Among Ukrainian Canadians. W. R. Petryshyn (ed.). Edmonton: The Canadian Institute of Ukrainian Studies. 78-96.

Lieberson. 1963. Ethnic Patterns in American Cities. New York: The Free Press of Glencoe.

Porter, John. 1965. The Vertical Mosaic. Toronto: University of Toronto Press. 
Madeline Kalbach, Kelly H. Hardwick, Renata D. Vintila, Warren E. Kalbach

Richard, Madeline A. 1991. Ethnic Groups and Marital Choices: Ethnic History and Marital Assimilation in Canada, 1871 to 1971. Vancouver, British Columbia, Canada: University of British Columbia Press.

Statistics Canada. 1992. 1991 Census Dictionary. Cat. 92-301E. Ottawa: Ministry of Industry, Science and Technology.

Statistics Canada. 1991. 1991 Census of Canada, Public Use Microdata File on Individuals.

Vintila, Renata D. 2000. The Persistence of Ethnic and Gender Inequality in Canadian Society. Master's thesis in Sociology, University of Calgary, Calgary.

Wanner, Richard A. 1998. "Prejudice, Profit, or Productivity: Explaining Returns to Human Capital Among Male Immigrants to Canada." Canadian Ethnic Studies, 30 (3): 24-55. 
Ethnic-Connectedness and Economic Inequality: A Persisting Relationship 